\title{
Investigating the Local Granulated Blast Furnace Slag
}

\author{
Mohamed Nacer Guetteche, Abdesselam Zergua, Samia Hannachi \\ Department of Civil Engineering, University Mentouri, Constantine, Algeria \\ Email: mnguetteche@yahoo.fr
}

Received January 21, 2012; revised February 27, 2012; accepted March 5, 2012

\begin{abstract}
The promotion of blast furnaces slag in construction industry aims at protecting the environment, fighting against the nuisance such as waste dumps and promoting local products. The use of granulated slag as a part replacement of Portland cement or in the production of clinker free binder constitutes a valuable outlet for this product. The aim of this study is the characterization of local granular slag using various techniques such as chemical analysis, $\mathrm{X}$ ray diffraction, differential thermal analysis, infrared spectrometry, and conductimetry. These methods provide a clearer understanding of the vitreous structure of this type of slag and also provide clues as to the nature of its hydraulic reactivity. Mechanical tests have been carried out using $4 \times 4 \times 16 \mathrm{~cm}^{3}$ prismatic mortars using a composition activated by the clinker, varying the fineness of slag, its content and the nature of clinkers. Results obtained show that this type of slag is reactive, the evolution of its mechanical resistance depends on its fineness, and that long-term mechanical performance is of great interest.
\end{abstract}

Keywords: Activation; Cement; Clinker; Mortar; Promotion; Slag

\section{Introduction}

Blast Furnace Slag is a by product of the steel industry. It is defined as "the non-metallic product consisting essentially of calcium silicates and other bases that is developed in a molten condition simultaneously with iron in a blast furnace" [1]. It results in the production of gas compounds (blast furnaces gas), of liquid (slag cast-iron), and of solid (gas dust). The granulated blast furnace slag may be used to make blast furnace slag cement either by being interground with the Portland cement clinker or by grinding the blast furnace slag separately and then blending it with cement. Each ton of cast-iron is necessarily followed up by a certain quantity of slag, which is variable according to the nature of the product fed in the kiln whether it is ore or combustible. This slag gathers in a liquid form of residual ore element in addition to gas and gas dust: such elements originate from ore gangue, fuel dust, or flux additions of a siliceous, calcareous or magnesium nature. The quantity of slag taking shape varies between 300 and $900 \mathrm{~kg}$ per ton of cast-iron in proportion according to the richness of ore content. The floating slag in a liquid state splits under the melting iron-cast gravity is evacuated through a casting hole [2]. El Hadjar's plant produces around $380 \mathrm{~kg}$ of slag per ton of cast-iron.

Following the method of solidification applied, the following products are obtained:

Vitrified slag, as a result of sudden cooling (by tempering), using water pressure leading to granular of a size varying between 0 and $5 \mathrm{~mm}$.

Crystallized slag obtained through a slow air-cooling is a hard angular rubbing rock.

Construction industry is one of the areas of solid wastes can be used in large quantities. Especially large amounts of natural resources are used in concrete production. In addition, the production of Portland cement which is a basic component of concrete causes the greenhouses gases production which causes global warming and climate change [3].

Mechanically activated granulated blast furnace slag was used in the range of $20 \%-75 \%$ to replace clinker in Portland slag cement. The slag and clinker were activated separately using a mill and mixed to prepare cement formulations [4].

Use of activated slag resulted in a remarkable increase in strength vis-à-vis slag cement. Both 2-day, 28-day and 90-day strength were found to increase with an increase in slag content up to $75 \%$. The strength of the sample containing $20 \%-75 \%$ slag was comparable to the commercial cement used as a reference. It was observed that mechanical activation of slag was more critical from the point of view of strength development.

\section{Experimental Program}

The main objective of this work is the characterization of the granular slag blast furnaces from El Hadjar, located in eastern Algeria, using various techniques $[5,6]$ and its 
investigation in order to utilize it as a basic component of cement. This is achieved through a chemical analysis, which allows the calculation of hydraulic indices, $\mathrm{X}$ rays diffractometry, thermal analysis, spectrometry, and conductimetry. The binding formula on a weight basis is as follows:

$\mathrm{X} 1 \%$ slag $+(100-\mathrm{X} 1) \%$ clinker $+5 \%$ gypsum

By varying:

The slag grinding degree such $\left(2000 \mathrm{~cm}^{2} / \mathrm{g}, 3750 \mathrm{~cm}^{2} / \mathrm{g}\right.$ and $6000 \mathrm{~cm}^{2} / \mathrm{g}$ ).

The slag content such $(20 \%, 30 \%, 40 \%, 50 \%, 60 \%, 80 \%)$.

The nature of the clinkers by using cement products used by the ERCEst (company of cement industry in Algeria).

The mechanical performances have been estimated by the use of the $4 \times 4 \times 16 \mathrm{~cm}^{3}$ mortar prisms.

\section{Characterization of the Constituents}

\subsection{Slag Chemical Analysis}

Slag is primarily made up of silica, alumina, calcium oxide, and magnesia. The exact concentrations of elements vary slightly depending on where and how the slag is produced.

When cement reacts with water, it hydrates and produces calcium silicate hydrate $(\mathrm{CSH})$. When blast furnace slag is added to the mixture, it also reacts with water and produces $\mathrm{CSH}$ from its available supply of calcium oxide and silica. A pozzolanic reaction also takes place which uses the excess $\mathrm{SiO}_{2}$ from the slag source,

$\mathrm{Ca}(\mathrm{OH})_{2}$ produced by the hydration of the Portland cement, and water to produces more of the desirable $\mathrm{CSH}$ making slag a beneficial mineral admixture to the durability of concrete [7]. Table 1 presents the chemical composition of the slag used in the present study.

\subsection{Basicity Module}

The calculation of the basicity module " $p$ " can be obtained by applying the following formulas $[3,4]$.

The symbol values are as follows:

$$
\begin{aligned}
& \mathrm{C}=\% \mathrm{CaO} ; \mathrm{S}=\% \mathrm{SiO}_{2} ; \mathrm{A}=\% \mathrm{AL}_{2} \mathrm{O}_{3} ; \mathrm{M}=\% \mathrm{MgO} \\
& \mathrm{P}_{1}=\mathrm{C} / \mathrm{S}=1.03 \\
& \mathrm{P}_{2}=(\mathrm{C}+\mathrm{M}) / \mathrm{S}=(37.22+3.55) / 35.84=1.13 \\
& \mathrm{P}_{2}=1.13
\end{aligned}
$$

We notice that: $\mathrm{P}_{1}>1, \mathrm{P}_{2}<1.5$.

So, the slag in question is basic which makes it appropriate for a possible use in the cements.

\subsection{Rays Diffraction}

The vitrified slag diffractograms shows a diffuse area, which characterizes the vitreous phase as well as a few low intensity rays that constitute the crystallized components. Figure 1 illustrates fairly well that the identified major crystalline phase corresponds to carbonates $\left(\mathrm{CaCO}_{3}\right)$, which confirmed by infrared analysis.

\subsection{Infrared Spectrometry (IRTF)}

Figure 2 shows the slag infrared spectrums for different specific blaine surfaces. The spectrum 1, 2, and 3 correspond respectively to specific Blaine surfaces of 2000 $\mathrm{cm}^{2} / \mathrm{g}, 3750 \mathrm{~cm}^{2} / \mathrm{g}$ and $6000 \mathrm{~cm}^{2} / \mathrm{g}$. The spectrum shows identified bands such as the $\mathrm{Ca}-\mathrm{O}, \mathrm{Si}-\mathrm{O}$ and the presence of carbonates characterized by the $876 \mathrm{~cm}^{-1}$. The peak determines this band, which tends to lose its shape and intensity in proportion to the increase of the Blain slaggrinding rate.

\subsection{Differential Thermal Analysis}

The weight of the samples and that of the warning light (calcinated Kaolin at $1000^{\circ} \mathrm{C}$ ) amount to $600 \mathrm{mg}$ and the rate of heating is $10^{\circ} \mathrm{C} / \mathrm{min}$.

The differential thermal analysis highlights two exothermic peaks reaching the temperature of $872^{\circ} \mathrm{C}$ and $906^{\circ} \mathrm{C}$, which correspond to (merwinite) $\left(\mathrm{C}_{3} \mathrm{MS}_{2}\right)$ and (gehlinite) $\left(\mathrm{C}_{3} \mathrm{AS}\right)$, as illustrated in Figure 3.

Table 1. Chemical composition of the slag.

\begin{tabular}{cc}
\hline Chemical composition & Content in (\%) \\
\hline $\mathrm{CaO}$ & 37.22 \\
$\mathrm{SiO}_{2}$ & 35.85 \\
$\mathrm{Al}_{2} \mathrm{O}_{3}$ & 5.08 \\
$\mathrm{MgO}$ & 3.55 \\
$\mathrm{Fe}_{2} \mathrm{O}_{3}$ & 7.77 \\
$\mathrm{MnO}$ & 2.02 \\
$\mathrm{Na}_{2} \mathrm{O}$ & 0.12 \\
$\mathrm{~K}_{2} \mathrm{O}$ & 0.27 \\
$\mathrm{TiO}_{2}$ & 0.17 \\
$\mathrm{P}_{2} \mathrm{O}_{5}$ & 0.09 \\
Loss on Ignition & 1.74 \\
\hline
\end{tabular}

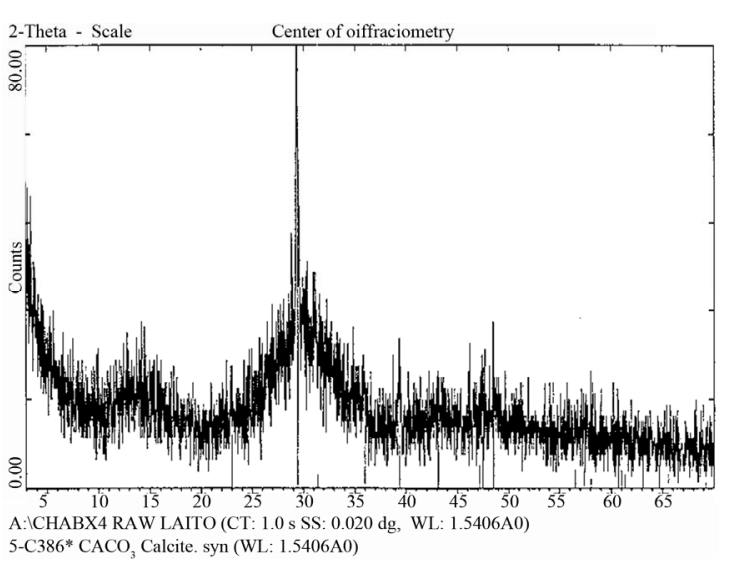

Figure 1. RX Diffractogram of used granulated slag. 


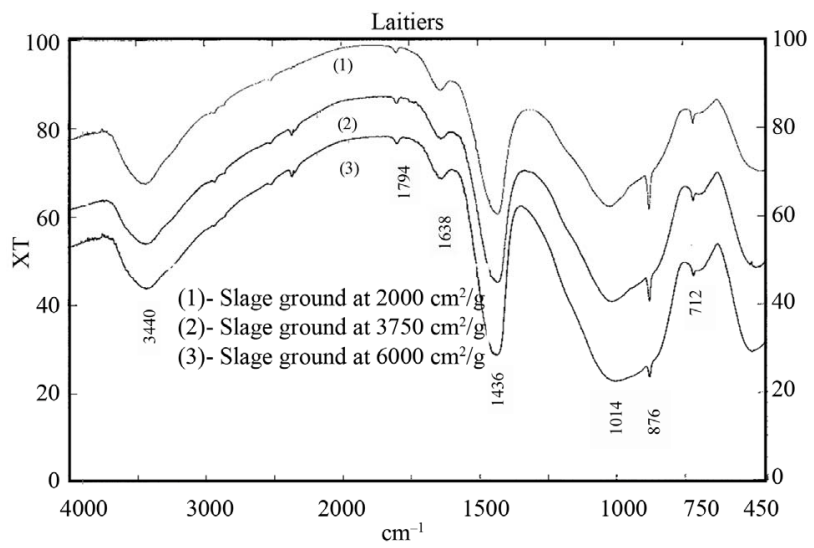

Figure 2. IR spectrometry of used granulated slag for various grinding rates.

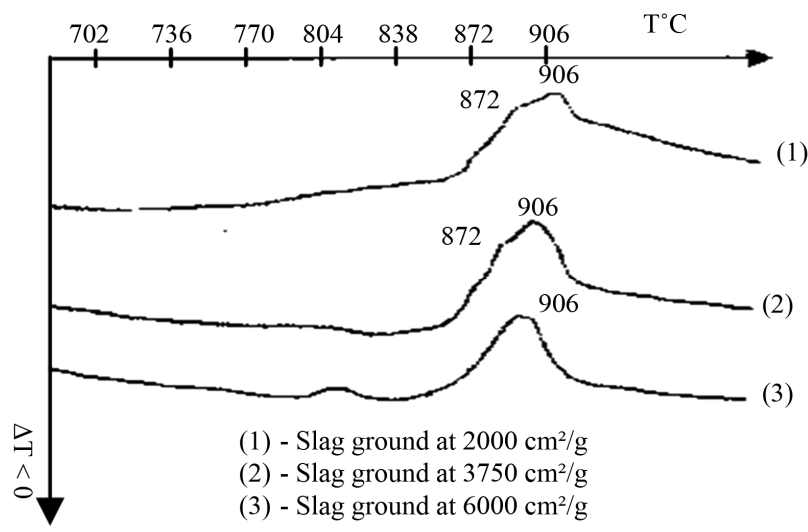

Figure 3. Thermal differential analysis “TDA" curve of used granulated slag.

\subsection{Conductimetry}

The "conductimetric" multiplexer allows to measure simultaneously the conductivity of nine suspensions (with a ratio of liquid/solid $=4$ ). These suspensions are contained in cylindrical cells and are shaken with the same speed using a hanging magnetic bar. The electrodes are stainless steel beltways placed on the cells periphery. The conductimeter is linked to a computer for data processing. The cells are placed in a temperature-regulated room at $20^{\circ} \mathrm{C}$. When slag is mixed with water. Figure 4 shows the conductivity for different slag. Dissolution of ions is nearly nil, and what is noticed is a weak conductivity not exceeding $0.4,0.5$, and $0.6 \mathrm{~ms} / \mathrm{cm}$ respectively for the three cases of grinding rate $\left(6000 \mathrm{~cm}^{2} / \mathrm{g}, 3750\right.$ $\mathrm{cm}^{2} / \mathrm{g}$ and $2000 \mathrm{~cm}^{2} / \mathrm{g}$ ).

From Figure 5, it may be concluded that slag is soluble only in the presence of activators. However, when the binder contains $76 \%$ of slag, $19 \%$ of APC (Artificial Portland Cement) and $5 \%$ of gypsum, the resulting conductivity values are considerably higher.

At the first stage, dissolution of clinker and gypsum compounds is noticed. It is an instantaneous increase in

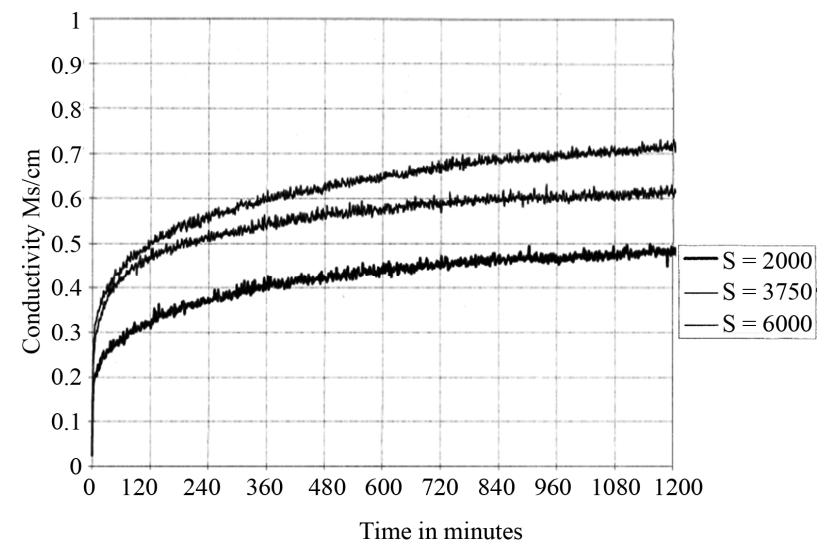

Figure 4. The conductivity of used granulated glag for various grinding rates.

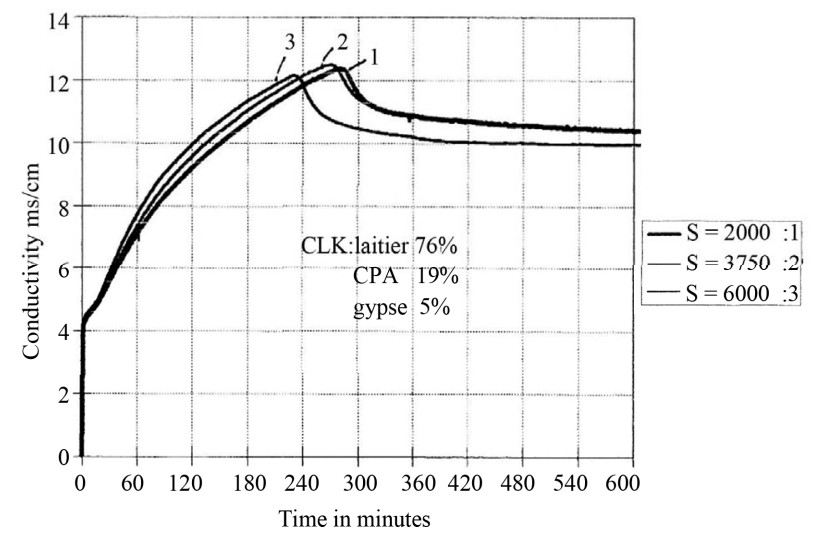

Figure 5. Influence of the clinker incorporation on the conductivity of used granulated slag for various grinding rates.

conductivity that reaches around a $6 \mathrm{~ms} / \mathrm{cm}$.

At the second stage: reactions continue forming probably (ettringite), C-S-H. The solution becomes richer in $\mathrm{Ca}^{2+}$ and a conductivity of about $12 \mathrm{~ms} / \mathrm{cm}$ is measured.

At the third stage, for a critical point of saturation in lime, the portlandite begins its precipitation leading to a sudden collapse in conductivity after reaching the peak of $12.5 \mathrm{~ms} / \mathrm{cm}$-value. It is noticed that conductivity reaches its maximum with time according to the slag grinding rate. Slag based binder ground at $6000 \mathrm{~cm}^{2} / \mathrm{g}$ comes first followed by that of $3750 \mathrm{~cm}^{2} / \mathrm{g}$, and, finally, the one with slag ground at $2000 \mathrm{~cm}^{2} / \mathrm{g}$.

The last stage constitutes the final period. The reactions are accelerated with the portlandite precipitation: the ions are consumed and a slow decrease in conductivity is observed.

\subsection{Characterization of Clinkers and Cement}

The clinkers used are manufactured products of ERCEst group in addition to OPC 55 French cement (Montalieu Vicat) of which the chemical and mineralogical compositions are illustrated in Tables $\mathbf{2}$ and $\mathbf{3}$. 
Table 2. Chemical composition of used clinker and cement.

\begin{tabular}{|c|c|c|c|c|c|c|c|}
\hline \multirow{3}{*}{$\begin{array}{l}\text { Chemical } \\
\text { composition }\end{array}$} & \multicolumn{7}{|c|}{ Chemical composition contents (in\%) } \\
\hline & \multicolumn{6}{|c|}{ For six types of clinker } & \multirow{2}{*}{$\begin{array}{c}\text { Cement } \\
\text { OPC55 }\end{array}$} \\
\hline & CK1 & CK2 & CK3 & CK4 & CK5 & CK6 & \\
\hline $\mathrm{CaO}$ & 64.84 & 65.19 & 64.68 & 67.14 & 65.74 & 63.94 & 62.52 \\
\hline $\mathrm{Al}_{2} \mathrm{O}$ & 4.96 & 5.11 & 4.43 & 4.75 & 5.16 & 5.90 & 4.64 \\
\hline $\mathrm{Fe}_{2} \mathrm{O}_{3}$ & 2.94 & 3.17 & 2.22 & 4.04 & 2.69 & 2.95 & 2.79 \\
\hline $\mathrm{SiO}_{2}$ & 21.47 & 21.81 & 23.46 & 22.91 & 21.74 & 22.57 & 21.07 \\
\hline $\mathrm{MgO}$ & 0.78 & 0.86 & 0.81 & 0.73 & 0.68 & 0.80 & 1.8 \\
\hline $\mathrm{SO}_{3}$ & 0.44 & 0.54 & 0.34 & 0.45 & 0.26 & 0.28 & $\mathrm{MnO}=0.03$ \\
\hline $\mathrm{Na}_{2} \mathrm{O}$ & 0.28 & 0.26 & 0.20 & 0.26 & 0.33 & 0.33 & 0.18 \\
\hline $\mathrm{K}_{2} \mathrm{O}$ & 0.81 & 0.94 & 1.03 & 0.28 & 0.67 & 0.81 & 1.01 \\
\hline $\mathrm{CL}$ & 0.03 & 0.02 & 0.02 & 0.01 & 0.01 & 0.01 & $\begin{aligned} \mathrm{TiO} & =0.24 \\
\mathrm{P}_{2} \mathrm{O}_{3} & =0.24\end{aligned}$ \\
\hline LOI\% & 0.05 & 0.05 & 0.05 & 0.05 & 0.05 & 0.05 & 1.78 \\
\hline Total & 96.60 & 97.95 & 97.32 & 100.4 & 97.32 & 97.64 & 96.02 \\
\hline
\end{tabular}

$\mathrm{CL}=$ Chloride, $\mathrm{LOI}=$ Loss on Ignition .

Table 3. Mineralogical composition of used clinkers and cement.

\begin{tabular}{|c|c|c|c|c|c|c|c|}
\hline \multirow{3}{*}{$\begin{array}{c}\text { Mineral } \\
\text { composition }\end{array}$} & \multicolumn{7}{|c|}{ Mineralogical composition contents (in\%) } \\
\hline & \multicolumn{6}{|c|}{ For six types of clinker } & \multirow{2}{*}{$\begin{array}{l}\text { Cement } \\
\text { OPC } 55\end{array}$} \\
\hline & CK1 & CK2 & $\mathrm{CK} 3$ & CK4 & CK5 & CK5 & \\
\hline $\mathrm{C}_{3} \mathrm{~S}$ & 57.11 & 54.38 & 45.76 & 56.53 & 58.27 & 39.22 & 59.175 \\
\hline $\mathrm{C}_{2} \mathrm{~S}$ & 18.49 & 21.49 & 32.75 & 23.03 & 18.36 & 35.12 & 15.777 \\
\hline $\mathrm{C}_{3} \mathrm{~A}$ & 8.18 & 8.19 & 8.16 & 5.28 & 9.13 & 10.66 & 7.575 \\
\hline $\mathrm{C}_{4} \mathrm{AF}$ & 8.95 & 9.64 & 6.76 & 12.31 & 8.18 & 8.97 & 8.49 \\
\hline
\end{tabular}

\subsection{Characterization of the Gypsum}

Gypsum used in this study is North African with the composition shown on Table 4.

\section{Mortar}

This study has been carried out using mortar prisms $4 \times 4$ $\times 16 \mathrm{~cm}^{3}$ prepared according to French standard NFP 15-411 and NFP 15-403 $24 \mathrm{~h}$ after casting. The prisms are stored in water (saturated in lime) at $20^{\circ} \mathrm{C}$ for the appropriate tests.

\section{Mechanical Properties}

Blast furnace slag has a positive effect on both the flexural and compressive strength of concrete after 28 days [5]. The real gain in strength is noticed after the 28 day mark especially when 120 grade GGBFS is used [8]. A 1992 study which showed that the flexural strength of concrete mixes with different slag replacement percentages was between 6.0 - 6.8 MPa at 14 days [9]. The long term strength of slag cement depends on many factors such as the amount of slag and Portland cement, and water to cement ratio.
Table 4. Gypsum chemical composition.

\begin{tabular}{cc}
\hline Chemical composition & Content in (\%) \\
\hline $\mathrm{CaO}$ & 18.86 \\
$\mathrm{AL}_{2} \mathrm{O}_{3}$ & 11.63 \\
$\mathrm{Fe}_{2} \mathrm{O}_{3}$ & 6.20 \\
$\mathrm{SiO}_{2}$ & 19.83 \\
$\mathrm{MgO}$ & 5.75 \\
$\mathrm{SiO}_{3}$ & 16.69 \\
$\mathrm{Na}_{3} \mathrm{O}$ & 0.03 \\
$\mathrm{~K}_{2} \mathrm{O}$ & 1.47 \\
$\mathrm{CI}$ & 0.026 \\
$\mathrm{Total}$ & 80.42 \\
$\mathrm{CaSO}+2 \mathrm{H}_{2} \mathrm{O}$ & 35.54 \\
\hline
\end{tabular}

Compressive and tensile test by bending are undertaken using a controlled moving press of $0.01 \mathrm{~mm} / \mathrm{min}$. Results obtained are shown on Tables $\mathbf{5}$ and $\mathbf{6}$.

\subsection{Effect of Slag Finesse}

Slag with grinding rate of $2000 \mathrm{~cm}^{2} / \mathrm{g}, 3750 \mathrm{~cm}^{2} / \mathrm{g}$ and $6000 \mathrm{~cm}^{2} / \mathrm{g}$ is introduced to produce slag-based cement with the mortar composition $76 \%$ slag $+19 \%$ clinker + $5 \%$ gypsum. Its effect on mechanical strengths displayed in Tables 5 and $\mathbf{6}$ shows that the higher strength is obtained for higher finesse.

The change in mechanical resistance according to the grinding rate is considerable as the increase of the former accompanies that of the latter. Indeed, when there is an increase in the grinding rate the grains contact surface becomes larger resulting in a strong chemical reactivity of this material. It could be concluded that slag grinding rate influences the final types of resistance. These results are in accordance with those obtained in $[10,11]$.

\subsection{Effect of Slag Content in One Type of Cement}

Several binders are prepared following the grinding rate of slag i.e. the $3750 \mathrm{~cm}^{2} / \mathrm{g}$ blaine specific surface and the slag content percentages which are gradually $20 \%, 30 \%$, $40 \%, 50 \%, 60 \%$, and $80 \%$.

In order to produce slag-based cements, a binder is prepared with the following composition:

$\mathrm{X} 1 \%$ Slag $+(100-\mathrm{X} 1) \% \mathrm{CPA}$ cement $+5 \%$ of Gypsum

Clinker used is French made CPA 55 cement (Mantalieu Vicat) with the chemical composition as displayed in Table 2.

\subsection{Effect on Mortar Resistance}

Compressive and tensile strengths at 2, 28, and 90 days are presented in Tables $\mathbf{7}$ and $\mathbf{8}$. The increase rate of strength depends at the first stage on slag content and secondly on the age of the test sampling. 
Table 5. Compressive strength for different mortars.

\begin{tabular}{ccccc}
\hline \multirow{2}{*}{ Mortar Type } & $\begin{array}{c}\text { Rate of fineness } \\
\left(\mathrm{cm}^{2} / \mathrm{g}\right)\end{array}$ & \multicolumn{3}{c}{ Compressive strength in MPa } \\
\cline { 3 - 5 } & 2000 & 1.20 & 6.80 & 18.40 \\
\hline M1 & 3750 & 2.00 & 17.10 & 29.20 \\
M2 & 6000 & 2.20 & 26.60 & 40.00 \\
M3 &
\end{tabular}

Table 6. Tensile strength for different mortars.

\begin{tabular}{ccccc}
\hline \multirow{2}{*}{ Mortar Type } & $\begin{array}{c}\text { Rate of fineness } \\
\left(\mathrm{cm}^{2} / \mathrm{g}\right)\end{array}$ & \multicolumn{3}{c}{ Compressive strength in MPa } \\
\cline { 3 - 5 } & 2000 & 0.40 & M1 & 2000 \\
\hline M1 & 3750 & 0.40 & M2 & 3750 \\
M2 & 6000 & 0.50 & M3 & 6000 \\
M3 &
\end{tabular}

Table 7. Tensile strength by bending for different binders.

\begin{tabular}{lccc}
\hline \multirow{2}{*}{$\begin{array}{l}\text { Composition of binders } \\
\left.\text { (Blaine specific surface }(\mathrm{SSB})=3750 \mathrm{~cm}^{2} / \mathrm{g}\right)\end{array}$} & \multicolumn{4}{c}{$\begin{array}{l}\text { Tensile strength by } \\
\text { bending (in MPa) }\end{array}$} \\
\cline { 2 - 4 } 2 days & 28 days & 90 days \\
\hline $20 \%$ slag $+75 \% \mathrm{CPA}+5 \%$ gypsum & 3.0 & 6.3 & 8.3 \\
$30 \%$ slag $+65 \% \mathrm{CPA}+5 \%$ gypsum & 2.5 & 6.2 & 8.3 \\
$40 \%$ slag $+55 \% \mathrm{CPA}+5 \%$ gypsum & 1.9 & 5.3 & 7.6 \\
$50 \%$ slag $+45 \% \mathrm{CPA}+5 \%$ gypsum & 1.3 & 5 & 6 \\
$60 \%$ slag $+35 \% \mathrm{CPA}+5 \%$ gypsum & 0.9 & 4.3 & 5.3 \\
$76 \%$ slag $+19 \% \mathrm{CPA}+5 \%$ gypsum & 0.4 & 4.2 & 7.3 \\
\hline
\end{tabular}

Table 8. Compressive strength for different binders.

\begin{tabular}{lccc}
\hline \multirow{2}{*}{$\begin{array}{l}\text { Composition of binders } \\
\text { (blaine specific surface }(\mathrm{SSB})=3750 \mathrm{~cm}^{2} / \mathrm{g} \text { ) }\end{array}$} & \multicolumn{4}{c}{$\begin{array}{c}\text { Compressive strength } \\
\text { (in MPa) }\end{array}$} \\
\cline { 2 - 5 } 2 days & 28 days & 2 days \\
\hline $20 \%$ slag $+75 \% \mathrm{CPA}+5 \%$ gypsum & 13 & 42 & 13 \\
$30 \%$ slag $+65 \% \mathrm{CPA}+5 \%$ gypsum & 12 & 0 & 12 \\
$40 \%$ slag $+55 \% \mathrm{CPA}+5 \%$ gypsum & 5.5 & 22 & 5.5 \\
$50 \%$ slag $+45 \% \mathrm{CPA}+5 \%$ gypsum & 4.0 & 20 & 4.0 \\
$60 \%$ slag $+35 \% \mathrm{CPA}+5 \%$ gypsum & 3.0 & 19 & 3.0 \\
$76 \%$ slag $+19 \% \mathrm{CPA}+5 \%$ gypsum & 2.0 & 17.8 & 2.0 \\
\hline
\end{tabular}

The effect on strength development of such an increase in slag content is observed on Tables 7 and 8. Indeed, the decrease in slag content in the mixture has sharply improved resistance at an early age. Such types of resistance increase in the 28 days test for the various grinding ratios; the gap between the types of resistance increases with time notably for the most important grinding rates.

The initial resistances after two days are low which is only normal as the hydration reactions of the slag based binders is slow and this is agree with the results issued from the literature. However, the long-term mechanical performances of these compositions are more or less significant.

\subsection{Effect of Clinker Type on Slag Reactivity}

It is well known that slag quality plays an important role in mechanical performances, but a lot of work is needed to enlighten the influence of the type of clinker.

In order to find out the best clinker in terms of activetion among the six types produced by the E.R.C Est, several binders have been prepared. The clinker, the OPC 55 and slag with grinding rate of $3750 \mathrm{~cm}^{2} / g$ were used.

The mixes were prepared according to the following composition:

$$
76 \% \text { Slag }+19 \% \mathrm{X}(\mathrm{X}=\text { CLINKER or OPC } 55)+5 \%
$$
Gypsum

\section{Results and Discussion}

The results show that the relationship between resistance in compression and the degree of hydration is complex. Besides its content in clinker and its grinding rate, each type of clinker has a considerable influence on the development of the slag based cement resistance. It has to be considered that each clinker type has a great influence on the development of the resistance of the blast furnaces slag based cement $[12,13]$. This is because not only the clinker activates slag but the situation can also be reversed and slag itself and its minor components may have a big influence on the development of the resistance of the clinker components.

The weak variation range of industrial clinkers and the uncertainty over the two days resistance do not allow a quantification of the clinker influence. Contrary to what has become widespread belief, resistances of cements, with strong content in slag, at an early age is principally in proportion to the quality of slag. The clinker reacts quickly and the measured resistance at the early age, i.e. the age of the slag-clinker association and not only that of the clinker on its own; the clinker quality has no noticeable influence before two days.

What needs to be taken into account is the fact that blast furnaces slag's cement while in hydration is a complicated multi-material system.

To sum up, all clinkers have well reacted with this type of slag; nevertheless, a slight difference in resistance is noticed especially that resulting at a medium term and a long one. The best resistances at 28 days are obtained with alite rich clinkers $\left(\mathrm{C}_{3} \mathrm{~S}\right)$ and tetragonal rich ones $\left(\mathrm{C}_{3} \mathrm{~A}\right)$. Even the alite rich clinker, which is weak in $\mathrm{C}_{3} \mathrm{~A}$, activates slag in a better way.

The results of the long-term mechanical tests show that regardless the type of clinker used, the performance in compressive strength is very significant. An average 
of $30 \%$ increase in resistance with regards to the findings recorded at 28 days is also noted. The major reasons of such increase are $\mathrm{C}_{3} \mathrm{~S}$ content and its quick reaction with water which provides an important degree of resistance. Finally, some additional observations may be made coessentially on the minor elements in clinkers chemical composition:

At 2 days, the $\mathrm{CK} 4$ clinker provides the best resistance which coincides with the greatest value of $\mathrm{C}_{4} \mathrm{AF}=12.31$ (alumino-ferrite tetracalcic).

The best mechanical performances are obtained at 28 days with clinkers containing higher $\mathrm{C}_{3} \mathrm{~S}$ content (alite) and higher $\mathrm{C}_{3} \mathrm{~A}$ (celite).

At 90 days the clinker based binder CK4 is the only one providing a weak resistance because of its low $\mathrm{C}_{3} \mathrm{~A}$ content of about 5.28.

It is worth mentioning that the alkali $\mathrm{Na}_{2} \mathrm{O}$ and $\mathrm{K}_{2} \mathrm{O}$, play an important role [14] in alkaline reactions. Indeed, at 90 days the best results are obtained with clinker based binders CK5 and CK6 which also coinciding with the best values of $\mathrm{Na}_{2} \mathrm{O}=0.33$.

\section{Conclusions}

The study undertaken on binder and slag based mortars leads to many observations that;

The chemical composition has shown that slag is basic (its ratio is nearing the unit 1), so it is reactive. When slag is simply mixed with water, dissolution of ions does not occur. On the other hand introduction of clinker and gypsum results in an important conductivity, which leads to the conclusion that slag is soluble only in alkalinized water.

Compressive and tensile strength by bending at 2, 28, and 90 days shows that the three binders is developing respectively at different rates according to the slag blaine grinding rate and the age of the samples.

The initial resistances at days two is low since the hydration reactions of the slag-based binders are very slow, which goes with the findings in the literature.

Mechanical strength development is very sensitive to the grinding ratio. When the grinding rate increases, mechanical resistance also increases. Indeed, when grinding increases contact surface of the grains becomes larger which results in a greater chemical reactivity. The slaggrinding rate intervenes in the final resistances, which is in line with the results issued from the literature.

The long term mechanical performances (90 days) of the slag-based compositions are of interest whatever the type of solicitation.

For the six slag-based binders, the speed of development is in relation with slag content, fineness rate, and age of the test prisms.

Generally, clinkers have well reacted with slag, but a slight difference in the resulting resistance is observed mainly at medium and long term. The best resistance at
28 days is obtained with higher $\mathrm{C}_{3} \mathrm{~S}$ and the $\mathrm{C}_{3} \mathrm{~A}$ content. It may also be noted that the minor elements play an important role in the slag reaction.

\section{REFERENCES}

[1] ASTM, "Standard Specification for Ground Granulated Blast-Furnace Slag for Use in Concrete and Mortars, ASTM C 989-99," American Society for Testing and Materials, West Conshohocken, Pa. ASTM C989, 1999, p. 5.

[2] L. Alexandre and J. L. Sebilleau, "Le Laitier de Haut Fourneau," Centre Technique et de Promotion des Laitiers, Paris, 1988, p. 340.

[3] S. Akçaözoğlu and C. D. Atiş, "Effect of Granulated Blast Furnace Slag and Fly Ash Addition on the Strength Properties of Lightweight Mortars Containing Waste PET Aggregates," Construction and Building Materials, Vol. 25, 2011, pp. 4052-4058. doi:10.1016/j.conbuildmat.2011.04.042

[4] S. Kumar, R. Kumar, A. Bandopadhyay, T. C. Alex, B. R. Kumar, S. K. Das and S. P. Mehrotra, "Mechanical Activation of Granulated Blast Furnace Slag and It Effect on the Properties and Structure of Portland Slag," Cement and Concrete Composites, Vol. 30, No. 8, 2008, pp. 679685. doi:10.1016/j.cemconcomp.2008.05.005

[5] H. G. Smolczyk, "Slags Structure and Typology," $7^{\text {th }}$ International Conference on Cement Chemistry, Paris, Vol. 3, 1980, pp. 1-3.

[6] A. Ouili, "Contribution to Blast Furnaces Alkaline Activation," Ph.D. Thesis, INSA de Lyon, Lyon, 1994, p. 153.

[7] V. Cervantes and J. Roesler, "Ground Granulated Blast Furnace Slag," Technical Note, Center of Excellence for Airport Technology, 2007, pp. 1-4

[8] F. Sajedi and H. A. Razak, "Effects of Thermal and Mechanical Activation Methods on Compressive Strength of Ordinary Portland Cement-Slag Mortar," Materials \& Design, Vol. 32, No. 2, 2011, pp. 984-995. doi:10.1016/j.matdes.2010.08.038

[9] E. Douglas, A. Bilodeau and V. M. Malhotra, "Properties and Durability of Alkali-Activated Slag Concrete," ACI Materials Journal, Vol. 89, No. 5, 1992, pp. 509-516.

[10] E. Von, "Slags Structure and the hydration of Cements: Discussions and Conclusions," $7^{\text {th }}$ International Conference on Cement Chemistry, Paris, Vol. IV, 1980, pp. 1-3.

[11] M. Ferreira, G. Liu, L. Nilson and O. C. Gjorv, "Blast Furnace Slag Cement for Concrete Durability in Marine Environment," Consec'04, Seoul, 23 June 2004, pp. 109116.

[12] F. Hawthorn, "Blast-Furnace Slags and Clinkers-Mutual Influences," $7^{\text {ème }}$ Congrès International de la Chimie des Ciments, Vol. 2, 1980, pp. 144-149.

[13] D. G. Mantel, "Investigation into the Hydraulic Activity of Five Granulated Blast Furnace Slags with Eight Different Portland Cements," ACI Material Journal, Vol. 1, No. 91, 1994, pp. 471-477.

[14] V. Baroghel-Bouny, "Caractérisation des Pâtes de Ciment et des Bétons-Méthodes, Analyse-Interprétations," LCPC, Paris, 1994, p. 468. 